\title{
Budaya Sekolah Menghafal Perkalian dan Membaca Buku Non Pelajaran Sebagai Peningkatan Literasi di Sekolah Dasar
}

\author{
Rodhiyah Dwi Agustin \\ PGSD STKIP Modern Ngawi dan rodhiyahdyah@gmail.com \\ Shiti Khairunisa \\ PGSD STKIP Modern Ngawi dan koirunnisa71@gmail.com
}

\begin{abstract}
Abstrak
Budaya sekolah di maknai dengan tradisi sekolah yang tumbuh dan berkembang sesuai dengan spirit dan nilai-nilai yang dianut di sekolah, artinya budaya sekolah ini berisi kebiasaan-kebiasaan yang disepakati bersama untuk di jalankan dalam waktu yang lama. Jika kebiasaan positif ini sudah membudaya, maka nilai-nilai karakter yang diharapkan akan terbentuk.Pada penelitian ini kami menggunakan jenis penelitian deskriptif untuk memperoleh gambaran mengenai budaya sekolah di SDN Mangunharjo 4. Sumber data yang kami peroleh yang pertama dari hasil wawancara dengan kepala sekolah, pengawas sekolah, guru dan tenaga kependidikan, dan siswa. Kedua hasil pengamatan di lapangan dengan keadaan lingkungan dan budaya yang ada di SDN Mangunharjo 4. Dari hasil pengamatan dan wawancara dengan kepala sekolah, pengawas sekolah, guru dan tenaga kependidikan, dan siswa kami dapat mengetahui implementasi budaya sekolah menghafal perkalian dan membaca buku non pelajaran di SDN Mangunharjo 4, sikap dan nilai-nilai setelah menerapkan budaya sekolah tersebut, manfaat dan tujuan, serta permasalahan atau pun kendala yang sering terjadi saat implementasi budaya sekolah tersebut. Sehingga kami berharap budaya ini dapat menjadi inprirasi untuk diterapkan di sekolah lain.
\end{abstract}

Kata kunci : Budaya Sekolah, Menghafal Perkalian, Membaca, Literasi

\section{PENDAHULUAN}

Manusia adalah makhluk yang berbudaya. Berbudaya merupakan kelebihan manusia di banding makhluk lain. Dengan berbudaya, manusia dapat memenuhi kebutuhan dan menjawab tantangan hidupnya. Manusia menggunakan akan dan budinya dalam berbudaya. Kebudayaan merupakan perangkat yang ampuh dalam sejarah kegidupan manusia yang dapat berkembang dan di kembangkan melalui sikap-sikap berbudaya yang mampu mendukungnya. Budaya juga menjadi garda depan dalam mendukung program pendidikan (Laksono et al., 2018)

Sama halnya dengan kebudayaan di sekolah. Budaya sekolah dimaknai dengan tradisi sekolah yang tumbuh dan berkembang sesuai dengan spirit dan nilainilai yang dianut di sekolah, artinya budaya sekolah ini berisi kebiasaan-kebiasaan yang disepakati bersama untuk di jalankan dalam waktu yang lama. Jika kebiasaan positif ini sudah membudaya, maka nilai-nilai karakter yang diharapkan akan terbentuk. Pandangan tentang budaya sekolah sudah ada sejak beberapa tahun silam. Pada tahun 1932 
menurut Willard Waller (Peterson dan Deal,2009:8) menyatakan bahwa setiap sekolah mempunyai kebudayaanya sendiri, yang berupa serangkaian nilai, norma, aturan, moral, dan kebiasaan, yang telah membentuk perilaku dan hubunganhubungan yang terjadi di dalamnya. Sementara itu Short dan Greer (1997) mendefinisikan budaya sekolah sebagai keyakinan, kebijakan, norma, dan kebiasaan di dalam sekolah yang dapat di bentuk, diperkuat, dan dipelihara pimpinan dan guru-guru disekolah. Budaya sekolah dengan demikian merupakan konteks di belakang layar yang menunjukan keyakinan, nilai, norma, dan kebiasaan yang telah dibangun dalam waktu yang lama oleh semua warga dalam kerja sama di sekolah. Budaya sekolah berpengaruh tidak hanya pada kegiatan warga sekolah, tetapi juga motivasi dan semangatnya. Seperti kita ketahui karakter adalah nilai-nilai yang melandasi perilaku manusia berdasarkan norma agama, kebudayaan, hukum/konstitusi, adat istiadat, dan estetika. Pendidikan karakter dimaknai sebagai pendidikan nilai, pendidikan budi pekerti, pendidikan moral, dan pendidikan watak; yang tujuannya mengembangkan kemampuan peserta didik untuk memberikan keputusan baik-buruk, memelihara apa yang baik, serta mewujudkan kebaikan itu dalam kehidupan sehari-hari dengan sepenuh hati (Kemendiknas, 2010). Kegiatan pembelajaran dari tahap kegiatan pendahuluan, inti, dan penutup; dipilih dan dilaksanakan agar peserta didik mempraktikan nilai-nilai karakter yang ditargetkan. Perilaku guru selama proses pembelajaran harus merupakan model pelaksanaan nilai-nilai bagi peserta didik. Artinya, guru harus senantiasa dapat menjadi teladan perilaku berkarakter bagi peserta didiknya sehingga dalam kurun waktu yang ditargertkan nilai-nilai karakter itu telah berubah menjadi kebiasaan atau dapat dikatakan habit yang membudaya, yaitu tahap akhir dari proses penanaman konsep. Pemerintah sekarang memang sedang giatgiatnya berbicara pentingnya pembentukan karakter.

\begin{tabular}{cccc}
\multicolumn{2}{c}{ Pemerintah } & Republik & Indonesia \\
melalui & Presiden & Susilo & Bambang
\end{tabular}
Yudhoyono pada tanggal 11 Mei tahun 2010; telah mencanangkan gerakan nasional pendidikan karakter. Menurut Komaruddin Hidayat (2010). Pembangunan sekolah terberat justru terletak pada membangun kultur sekolah ini, karena selain membutuhkan dana yang tidak sedikit, juga membutuhkan daya tahan kesabaran, keuletan, presistensi, dan konsistensi, dari seluruh pemangku kepentingan di sekolah yaitu kepala sekolah, guru, orang tua, masyarakat, dan pemerintah. Budaya sekolah dapat berupa berbagai macam kegiatan, salah satunya adalah budaya Gerakan Literasi Sekolah. Budaya sekolah ini mulai di terapkan pada berbagai sekolah dasar. Literasi adalah istilah umum yang merujuk kepada seperangkat kemampuan dan keterampilan individu dalam membaca, menulis, berbicara, menghitung, dan memecahkan masalah pada tingkat keahlian tertentu yang diperlukan dalam kehidupan sehari-hari. Gerakan Literasi ini bertujuan menumbuh kembangkan budi pekerti peserta didik melalui pembudayaan ekosistem literasi sekolah. prestasi belajar siswa tidak saja dipengaruhi oleh kemampuan siswa dalam menerima pelajaran saja, akan tetapi juga dapat dipengaruhi oleh kemampuan gurunya yang mampu membangkitkan minat dan motivasi siswa pada saat diajar, maka sudah barang tentu akan sangat membantu siswa utuk dapat menerima pelajaran tersebut dengan sebaik-baiknya (Supriyanto, 2010). 
Program ini dilaksanakan sesuai dengan peraturan yang telah dikeluarkan sebelumnya yaitu Permendikbud Nomor 23 Tahun 2015 tentang penumbuhan budi pekerti. Salah satu program yang di canangkan adalah 15 menit membaca buku non mata pelajaran sebelum waktu pelajaran dimulai kegiatan ini dilaksanakan untuk menumbuhkan minat baca peserta didik serta meningkatkan keterampilan membaca agar pengetahuan dapat dikuasai lebih baik. Materi baca dapat berisi nilai-nilai budi pekerti berupa kearifan lokal, nasional, dan global yang di sampaikan sesuai tahap perkembangan peserta didik. Tentu akan sulit bagi anak untuk memiliki kesempatan membaca buku non pelajaran, karena mereka sudah disibukan dengan pekerjaan rumah maupun interaksi sosial dengan masyarakat. Media pembelajaran jembatan zebra ini dirancang untuk meningkatkan pemahaman dan hasil belajar matematika siswa materi satuan pengukuran di sekolah dasar (Supriyanto, 2017). Maka dari itu gerakan litersi sekolah dijadikan senagai salah satu budaya sekolah dan diharapkan dapat menjadi kebiasaan positif yang di terapkan di SDN Mangunharjo 4. Perlunya pendampingan oleh guru kelas masingmasing agar budaya sekolah dapat berjalan dengan lancar. Tidak hanya membaca budaya sekolah menghafal perkalian juga mulai ditepapkan di SDN Mangunharjo 4. Budaya ini diterapkan mulai kelas 1-6 dan setiap harinya siswa menghafalkan perkalian yang berbeda.

Budaya sekolah ini juga salah satu wujud penerapan budaya sekolah dengan tujuan meningkatkan kemampuan berhitung siswa. Jadi pada budaya sekolah ini lebih menitik beratkan pada keterampilan dan kemampuan berhitung siswa. Seperti kita ketahui mata pelajaran matematika merupakan mata pelajaran yang kurang diminati oleh siswa, karena menurut mereka matematika itu sulit, sehingga matematika menjadi momok yang menakutkan bagi siswa bahkan sebelum mempelajari matematika siswa sudah memiliki pandangan bahwa matematika merupakan suatu mata pelajaran yang sulit untuk dipelajari. Padahal matematika termasuk mata pelajaran yang penting bagi siwa terutama disekolah dasar dan menjadi bekal mereka untuk meneruskan pendidikan ke jenjang smp. Sikap siswa terhadap matematika dimaksudkan sebagai perasaan siswa tentang obyek, aktivitas, peristiwa yang terjadi disekitarnya, perasaan ini menjadi konsep yang merepresentasikan suka atau tidak sukanya seseorang pada sesuatu terhadap matematika yang didasarkan pada pengetahuan atau perasaannya terhadap matematika, pada pembelajaran guru mengajar diartikan sebagai upaya mengorganisir lingkungan pada saat pembelajaran (Rahmawati, Arum Dwi; Supriyanto, 2018).

Untuk mengatasi masalah tersebut salah satunya dengan menerapkan budaya menghafal perkalian setiap akan dimulainya mata pelajaran tepatnya sesudah mereka membaca buku non pelajaran siswa dilanjutkan menghafal perkalian. Dari sebuah analisis yang kami lakukan rata-rata siwa kelas 1-5 di salah satu sekolah dasar masih banyak siswa yang belum hafal perkalian, ada pun yang hafal akan tetapi hanya sedikit dan termasuk sangat minoritas. Dengan di terapkannya budaya sekolah menghafal perkalian dapat mengasah siswa dalam berhitung dengan menghafal perkalian. Kami juga berharap dengan diterapkannya budaya sekolah menghafal perkalian ini dapat mencapai tujuan dan manfaat yang ingin kami capai yaitu dapat meningkatkan kemampuan literasi siswa, menanamkan kedisiplinan pada siswa, 
menanamkan karakter tanggung jawab, percaya diri, memiliki jiwa nasionalis.

\section{METODE}

Sesuai dengan masalah yang kami teliti yaitu budaya sekolah menghafal perkalian dan membaca sebagai wujud literasi siswa di SDN Mangunharjo 4 kami menggunakan jenis penelitian deskriptif untuk memperoleh gambaran mengenai budaya sekolah di SDN Mangunharjo 4. Sumber data yang kami peroleh yang pertama dari hasil wawancara dengan kepala sekolah, pengawas sekolah, guru dan tenaga kependidikan, dan siswa. Kedua hasil pengamatan di lapangan dengan mengamati keadaan lingkungan dan budaya yang ada di SDN Mangunharjo 4. Lokasi penelitian yang kami lakukan berada di desa Mangunharjo dusun krawut kecamatan Ngawi kabupaten Ngawi.

\section{PEMBAHASAN}

Berdasarkan pengamatan penerapan budaya sekolah di SDN Mangunharjo 4 Budaya Sekolah menghafal perkalian dan membaca buku non pelajaran dilaksanakan setiap hari dengan urutan sebagai berikut : (1) pertama siswa di bariskan di depan kelas dengan dipimpin oleh ketua kelas masing-masing; (2) Ketua kelas memberikan aba-aba kepada teman-temannya dan meluruskan barisan; (3) Siswa memeriksa kerapian diri mereka masing-masing; (4) Ketua kelas memilih barisan yang paling lurus untuk masuk ke dalam kelas terlebih dahulu; (5) Setelah itu siswa duduk di tempat masing-masing; (6) Guru memandu siswa melalui pengeras suara dari kantor untuk berdoa bersama; (7) Siswa membacakan pancasila, janji siswa, dan menyanyikan lagu nasional; (8) Siswa di harap membaca buku non pelajaran yang telah disediakan di perpustakaan dan kembali ke kelas masing-masing; (9) Siswa diminta membaca buku yang telah mereka ambil di perpustakaan kurang lebih 15 menit; (10) Setelah itu siswa menghafal perkalian bersama-sama dan setiap hari nya siswa meghafalkan perkalian yang berbeda-beda: (11) Guru memulai pembelajaran sesuai dengan mata pelajaran.

Sikap dan nilai-nilai karakter yang terbentuk setelah penerapan budaya sekolah menghafal perkalian dan membaca buku non pelajaran. Banyak nilai dan sikap yang dapat dan harus ditanamkan disekolah. Sekolah adalah laksana taman atau lahan yang subur tempat menyampaikan dan menanam benihbenih nilai tersebut. Dengan diterapkannya budaya menghafal perkalian dan membaca buku non peljaran dapat membentuk sikap dan nilai-nilai karakter pada siswa diantaranya: 1) jujur dan bertanggung jawab, 2) cerdas 3) memiliki wawasan yang luas 4) peduli dan kreatif.

Tujuan dan manfaat diterapkannya budaya sekolah menghafal perkalian dan membaca buku non pelajaran antara lain : (1) melatih kedisiplinan siswa. Dengan diterapkannya budaya sekolah tersebut dapat melatih belajar koknitif siswa. Hal tersebut berkaitan dengan pemrosesan informasi di pikiran siswa. Informasi yang di proses oleh otak pembelajaran yang berupa konsep, prosedur, dan prinsip-prinsip. Menurut Charles M. Reigeluth (1989) membagi tahap-tahap belajar koknitif menjadi tahap pengingatan (memorisasi), tahap pemahaman, dan tahap penerapan. Menghafal perkalian termasuk ke dalam tahap pengingat (memorisasi) serta tahap pemahaman dan penerapan dapat diterapkan melalui budaya membaca buku non pelajaran. (2) Melatih rasa tanggung jawab dan percaya diri siswa. Budaya sekolah menghafal perkalian secara tidak langsung dapat melatih rasa tanggung jawab dan percaya diri siswa. Setiap hari siswa diminta untuk menghafalkan perkalian melalui 
pengeras suara yang ada di ruang guru secara bergantian. Siswa juga di beri tanggung jawab untuk memandu teman-teman mereka untuk menghafal perkalian. (3) Melatih siswa untuk gemar membaca. Kebiasaan yang positif membaca buku akan membuat siswa terbiasa. Terutama buku bacaan non pelajaran yang tergolong jarang mereka baca. Siwa yang semula tidak suka membaca mau tidak mau akan perlahan gemar membaca. Karena itulah budaya sekolah ini mulai diterapka di berbagai sekolah dasar salah satunya di SDN Mangunharjo 4. Begitu pula dengan menghafal perkalian. Kebiasaan menghafal perkalian dapat sedikit demi sedikit dapat meningkatkan daya ingat siswa dengan menghafal perkalian.

Kendala diterapkannya budaya sekolah menghafal perkalian dan membaca buku non pelajaran yaitu siswa yang cenderung hiperaktif terkadang sulit untuk diatur. Siswa tersebut dapat juga mempegaruhi siswa lainnya. Siswa seperti kurang antusias dengan di terapkannya budaya sekolah tersebut sehingga budaya sekolah sering kali kurang berjalan dengan lancar. Guru dan tenaga pendidikan yang kurang mendukung dengan budaya sekolah yang diterapkan oleh kepala sekolah. Mereka kurang setuju dengan program yang di canangkan oleh kepala sekolah. Menurut mereka budaya tersebut hanya mempersulit siswa dan membuat siswa tertekan dengan program tersebut Terkadang kebiasaan yang baik harus sedikit di paksa, akan tetapi apabila budaya sekolah tersebut telah berjalan dengan baik akan bermanfaat bagi perkembangan siswa dan menjadi bekal mereka melanjutkan jenjang pendidikan yang lebih tinggi.

\section{PENUTUP}

\section{Simpulan}

Budaya sekolah menghafal perkalian dan membaca buku non pelajaran dapat membentuk sikap dan nilai-nilai karakter yang terbentuk setelah penerapan budaya sekolah menghafal perkalian dan membaca buku non pelajaran. Banyak nilai dan sikap yang dapat dan harus ditanamkan disekolah. Sekolah adalah laksana taman atau lahan yang subur tempat menyampaikan dan menanam benih-benih nilai tersebut. Dengan diterapkannya budaya menghafal perkalian dan membaca buku non peljaran dapat membentuk sikap dan nilai-nilai karakter pada siswa diantaranya: 1) jujur dan bertanggung jawab, 2) cerdas 3) memiliki wawasan yang luas 4) peduli dan kreatif.

\section{Saran}

Dengan diterapkannya budaya sekolah menghafal perkalian dan membaca buku non pelajaran ini dengan baik di SDN Mangunharjo 4 dapat menjadi ispirasi ataupun panutan bagi sekolah dasar lainnya. Sehingga kebiasaan yang positif dapat membudaya di berbagai sekolah dasar.

\section{DAFTAR PUSTAKA}

Nurcahyo, Abraham dkk.2010.Ilmu Sosial dan Budaya Dasar.Magetan: LESwastika Press.

Salirawati, Das.2018.Smart Teaching Solusi Menjadi guru Profesional. Jakarta: Bumi Aksara.

Darmiatun, Suryatri, Daryanto.2013. Implementasi Pendidikan Karakter Pendidikan di Sekolah Dasar. Yokyakarta:Gava Media.

Farid, Muhammad, Daryanto. 2013. Konsep Dasar Manajemen Pendidikan Di Sekolah.Yogyakarta:Gava Media.

Laksono, B. A., Supriyono, \& Wahyuni, S. (2018). an Investigation of Local Wisdom To Support Adult Literacy Program. PEOPLE: International 
Journal of Social Sciences, 4(2), 1320 1336.

https://doi.org/10.20319/pijss.2018.42.1 3201336

Rahmawati, Arum Dwi; Supriyanto, D. H. (2018). Pengaruh Model Pembelajaran Kooperatif Tipe TPS Terhadap Prestasi Belajar Matematika Siswa Kelas IV SDN Wakah. Prosiding Seminar Nasional Etnomatnesia, 1(6), 790-794.

Supriyanto, D. H. (2010). Peningkatan Motivasi Dan Prestasi Belajar Matematika Dengan Menggunakan Media Styrofoam Kelas III SDN Tambakromo II Kecamatan Padas
Kabupaten Ngawi. 2005(19).

Supriyanto,

D.

$\mathrm{H}$.

(2017).

PENGEMBANGAN

MEDIA

JEMBATAN ZEBRA PADA MATERI SATUAN. 70-74.

Rias Wana, Prima, Pradistya Arifah Dwiarno. 2018. Implemnetasi Pendekatan Scientific Untuk Meningkatkan Budaya Literasi di sekolah Dasar.5(2):135-136

Mustofa, Edi. 2018. Lima Budaya Sekolah Pembentuk Karakter (pena.belajar.kemendikbud.go.id) (diakses tanggal 10 januari 2020) 